
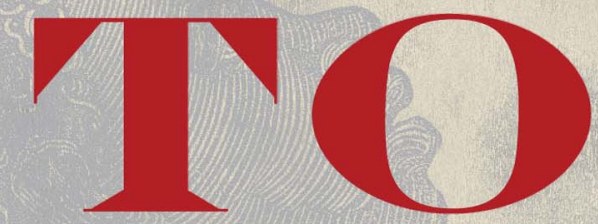

\title{
African Americans
}

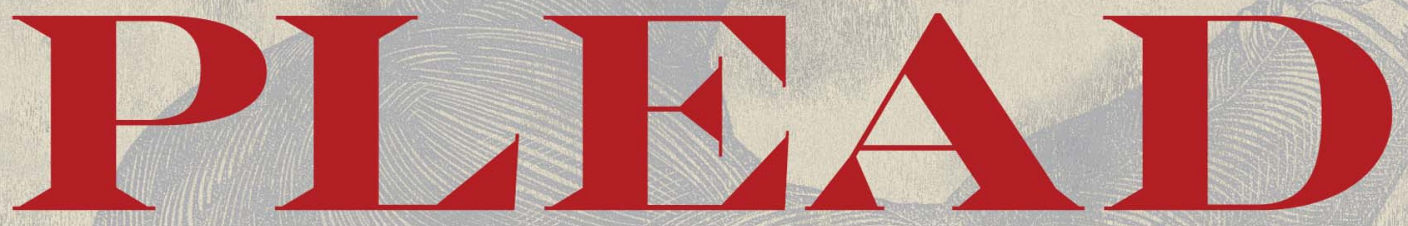

in Massachusetts

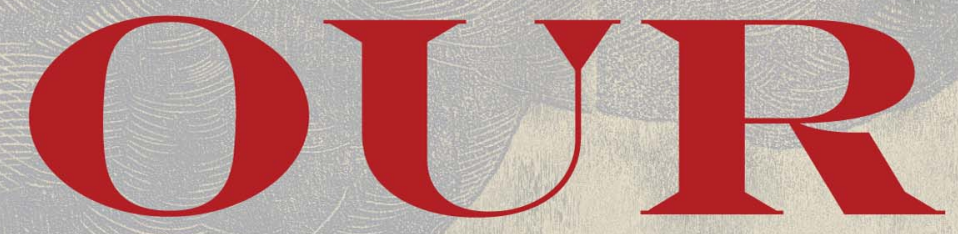

\section{and the}

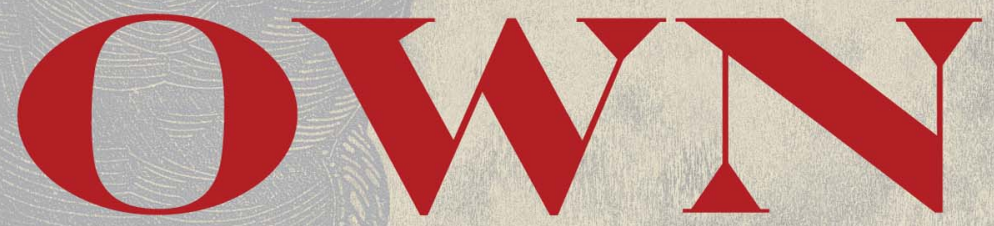

\section{Making of the}
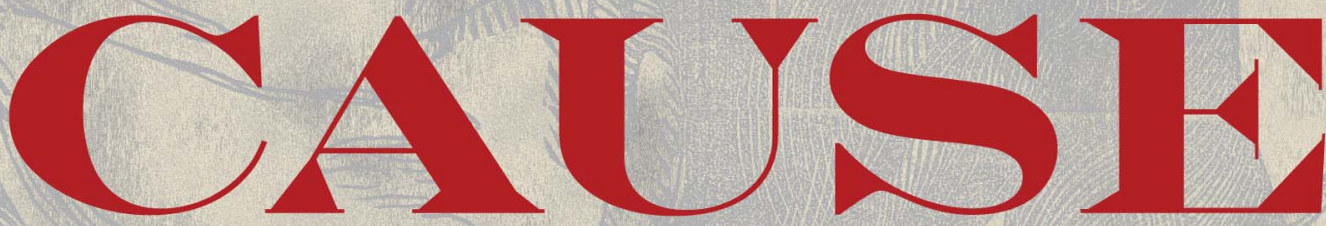

Antislavery Movement

Christopher Cameron 


\section{AMERICAN ABOLITIONISM AND ANTISLAVERY John DAVID SMith, SERIES EDITOR}

The Imperfect Revolution: Anthony Burns and the Landscape of Race in Antebellum America GORDON S. BARKER

A Self-Evident Lie: Southern Slavery and the Threat to American Freedom JEREMY J. TEWELL

Denmark Vesey's Revolt: The Slave Plot That Lit a Fuse to Fort Sumter JOHN LOFTON NEW INTRODUCTION BY PETER C. HOFFER

To Plead Our Own Cause: African Americans in Massachusetts and the Making of the Antislavery Movement CHRISTOPHER CAMERON 


\section{To Plead Our Own Cause}

African Americans in Massachusetts and the Making of the Antislavery Movement

Christopher CAmeron

ब2x

THE KENT STATE UNIVERSITY PRESS

Kent, Ohio 
(C) 2014 by The Kent State University Press, Kent, Ohio 44242

ALL RIGHTS RESERVED

Library of Congress Catalog Card Number 2013042583

ISBN 978-1-60635-194-9

Manufactured in the United States of America

LIBRARY OF CONGRESS CATALOGING-IN-PUBLICATION DATA

Cameron, Christopher, 1983-

To plead our own cause : African Americans in Massachusetts and the making of the antislavery movement / Christopher Cameron.

pages $\mathrm{cm}$. - (American abolitionism and antislavery)

Includes bibliographical references and index. ISBN 978-1-60635-194-9 (hardcover) $\infty$

1. African American abolitionists-Massachusetts-History. I. Title.

$$
\begin{gathered}
\mathrm{E}_{445 . \mathrm{M}_{4} \mathrm{C} 362014} \\
3266^{\prime} .80922-\mathrm{dc} 23 \\
2013042583
\end{gathered}
$$

$$
\begin{array}{llllllllll}
18 & 17 & 16 & 15 & 14 & 5 & 4 & 3 & 2 & 1
\end{array}
$$




\section{Contents}

Acknowledgments vii Introduction 1

1 Puritans and Slavery 8

2 Black Abolitionist Writers in the Age of Revolution 29

3 Black Petitioning and Organized Abolitionism in Revolutionary Massachusetts 50

4 Abolition of Slavery and the Slave Trade 70

5 Massachusetts Blacks and the Growth of the Northern Antislavery Movement 84

6 Black Emigration and Abolition in the Early Republic 100

7 Abolitionism and the Politics of Slavery in Early Antebellum Massachusetts 114

Afterword 133

Notes 136

Bibliography 155

Index 169 


\section{Introduction}

In one of the most significant antislavery tracts published in antebellum America, Appeal to the Coloured Citizens of the World (1829), David Walker, a black activist residing in Boston, articulated many of the most prominent themes in American abolitionism, including a rejection of the colonization plan, a call for black unity, and the idea that God would be on the side of the oppressed. "Though our cruel oppressors and murderers, may (if possible) treat us more cruel, as Pharoah did the children of Israel," Walker wrote, "yet the God of the Etheopeans, has been pleased to hear our moans in consequence of oppression; and the day of our redemption from abject wretchedness draweth near, when we shall be enabled, in the most extended sense of the word, to stretch forth our hands to the LORD our GOD." ${ }^{1}$ Walker argued that even though whites treated blacks cruelly, God was on their side and would answer their cries for freedom. Central to Walker's vision of freedom for blacks was the assistance of the Almighty. At the same time, though, Walker argued that African Americans must take the initiative and work to free themselves. "There must be a willingness on our part, for GOD to do these things for us," he argued, "for we may be assured that he will not take us by the hairs of our head against our will and desire, and drag us from our very, mean, low and abject condition."

While most studies of the antislavery movement begin their examination in the 1820 s, Walker's blend of religious and political rhetoric in the cause of abolitionism was a tactic African Americans had employed in the fight against slavery since the eighteenth century. One such predecessor was a 
free black man named Caesar Sarter of Newburyport, Massachusetts, who published an essay on slavery in 1774 asking supporters of slavery, "Why, in the name of Heaven, will you suffer such a gross violation of that rule by which your conduct must be tried, in that day, in which you must be accountable for all your actions, to, that impartial Judge, who hears the groans of the oppressed and who will sooner or later avenge them of their oppressors!"3 As Walker would later do, Sarter argued that a righteous God would be on the side of slaves and would judge America for the sin of slavery.

It is a common understanding in the scholarship on abolitionism that the radical abolitionist movement did not begin until the 1830s. David Walker's Appeal and William Lloyd Garrison's publication of the Liberator beginning in 1831 are seen as the opening salvos in this new, radical phase of the antislavery movement. Sarter's rhetoric and calls for immediate emancipation, however, along with that of many of his contemporaries in Massachusetts, suggest that eighteenth-century abolitionism was just as radical as its nineteenth-century counterpart and that the origins of abolitionism in America can be found among blacks in Massachusetts. This is the first study to trace these origins to African Americans in the Bay State and explore the significance of Calvinism to their antislavery ideology.

The demographics of Massachusetts, rights given to slaves within the colony, and the injunction of ministers to Christianize slaves aided in the formation of a black community that began to challenge slavery in the public sphere during the revolutionary period. In Massachusetts, slavery itself was shaped heavily by Old Testament law, which said that slaves should have specified rights. Thus, early Puritans allowed slaves to petition the government and bring cases in court. Furthermore, religious leaders in the colony urged their parishioners to Christianize slaves, a practice that extant church records indicate was followed by a number of owners. The fact that slaves never made up more than 5 percent of the colony's population and the lack of overt rebellions (such as the 1739 Stono Rebellion in South Carolina) made the colony more conducive to allowing slaves liberties that they were summarily denied elsewhere.

The centrality of Massachusetts in Revolution-era politics also greatly contributed to black political activity, as blacks both drew from and critiqued whites' religious tenets and political arguments for freedom from British rule to argue for freedom from slavery. Blacks in Boston began 
making these arguments in the public sphere in 1773 by presenting petitions that employed religious rhetoric similar to what Sarter would use one year later, transforming Reformed theology into an argument for abolition. Petitioning was the most successful strategy black activists employed, as it pushed the Massachusetts General Court to consider laws abolishing slavery on more than one occasion and was partly responsible for the 1788 law prohibiting slave trading among state residents. Other tactics included publishing essays and books of poetry, suing for freedom, and creating institutions to serve as the basis for antislavery organizing.

Among these institutions was the first antislavery committee in America. While this honor is usually reserved for the Pennsylvania Abolition Society, first organized in 1775, a committee representing slaves in Massachusetts formed by 1773 and began its campaign to bring about abolition. They first petitioned the General Court in 1773, and records indicate that its efforts spurred the colonial legislature to pass an abolition bill the next year. After Prince Hall formed the African Masonic Lodge in 1775, that body took the lead in future petitions, again spurring the Massachusetts General Court to consider an abolition bill in 1777 and later calling for equal access to educational facilities in the state. The African Masonic Lodge would continue to play a vital role in Boston's black community and the larger abolitionist movement from the revolutionary era through the 1830 s.

Along with more traditional forms of abolitionist organization, this book explores the black emigration movement of the late eighteenth and early nineteenth centuries and argues that emigration was an important component of antislavery activity during this period. African American leaders such as Paul Cuffe and Prince Saunders proposed emigration to Sierra Leone and Haiti as a means of both thwarting the international slave trade and inducing southern slaveholders to liberate their bondmen. Some masters argued that they could not free their slaves because it was unclear what their political and social status would be in America, so emigration emerged as a strategy that could alleviate this concern. While this movement never had the impact that Cuffe or Saunders envisioned, it served the practical purpose of connecting black leaders across the North and providing for cooperation between white and black abolitionists throughout the Atlantic world.

In the late $1820 \mathrm{~s}$, the national antislavery movement was centered in Boston, a phenomenon I trace to its origins through an examination of 
blacks' community-building efforts in Massachusetts in the years of the early republic. By doing this, I hope to shed new light on both the study of the "first emancipation," the period in which African Americans gained freedom in the North, and blacks' broader struggle for the freedom of all slaves in the early nineteenth century. Furthermore, while the subjects of this book are located in Massachusetts, I examine the broader contributions of African Americans to the political and religious ideology of America in its earliest years and the ways in which developments in England, Africa, and the Caribbean informed black abolitionism in Massachusetts. As such, this study is both a social and intellectual history of black abolitionists that places their actions within the context of global freedom struggles by whites and blacks from the era of the American Revolution to the antebellum period.

The field of abolitionist studies has certainly thrived over the years, and there have been a number of excellent works published in this area, yet few have examined the important relationship between Reformed theology and black abolitionism, and even fewer stretch their analyses back into the eighteenth century. In the first definitive study of the northern antislavery movement, Arthur Zilversmit claimed that "the history of the early abolitionist movement is essentially the record of Quaker antislavery activities," a claim that effectively excluded blacks, none of whom belonged to the Society of Friends or were allowed to participate in abolitionist organizations that Quakers ran in the eighteenth century. ${ }^{4}$ While Zilversmit's study, along with Brycchan Carey's recent analysis of antislavery rhetoric, focuses primarily on Quaker abolitionists, David Brion Davis has examined the foundations of antislavery ideology throughout the Atlantic world in the Age of Revolution. Despite the sweep of Davis's seminal works, he slights the importance of blacks' antislavery thought and activities. More recently, historians such as Margot Minardi have explored the significance of eighteenth-century abolitionism, yet her important book Making Slavery History is concerned more with the memory of early abolitionists than the activists themselves. ${ }^{5}$ Richard Newman's Transformation of American Abolitionism examines the movement in Pennsylvania during the eighteenth century, arguing for a shift from gradual to immediate emancipation by the $1830 \mathrm{os} .{ }^{6}$ In this book I challenge Newman's perspective by arguing that Massachusetts was at the center of the abolitionist movement from its in- 
ception and that calls for immediate emancipation were present in blacks' writings from the $1770 \mathrm{os}$.

Those scholars who have focused on the political activity of black abolitionists have centered their attention primarily on the years after 1830 . This is due to a misconception among historians such as Benjamin Quarles and Herbert Aptheker that early black abolitionists were too conservative in their approach and did not have a significant impact on the achievement of abolition. These scholars argue that most black abolitionists after 1830 were more radical because they called for an immediate end to slavery as opposed to its gradual abolition. This separation of radicalism versus conservatism into disparate time periods is no longer adequate. Black abolitionists articulated arguments that were best suited to their time period and local context. For some, this meant supporting gradual emancipation plans. But for most it meant arguing for an immediate end to slavery in no uncertain terms. I argue that the radical abolition movement did not begin during the antebellum period but, rather, in Revolution-era Massachusetts. ${ }^{7}$

Even as there has been an increasing amount of scholarship on nineteenth-century black abolitionists, there remains a dearth of literature on early black intellectual history. However, Mia Bay, Patrick Rael, and Laurie Maffly-Kipp, among others, have made important contributions to this field. Bay examines the racial ideology of African Americans toward whites in the period from 1830 to 1925 , in part because she found a lack of sources for this topic in the earlier period. Rael's work has a shorter chronological focus, examining identity building in black communities between 1820 and 1860, while Maffly-Kipp explores the production of "race histories" from the late eighteenth century to the 1920s. I complement these important additions to the field by examining not only the political activity of black abolitionists in the eighteenth century but also the ideological origins of their political thought. ${ }^{8}$

In Massachusetts, these ideological origins lie primarily in late-seventeenth- and early-eighteenth-century Puritan thought, which shaped both the religious beliefs and political activity of black abolitionists in the late eighteenth century. John Saillant has made the connection between Puritanism and black politics in his biography of black abolitionist Lemuel Haynes, in which he argues that Haynes blended republican political philosophy with the New Divinity theology that dominated late-eighteenth-century 
Calvinism in his critiques of the institution of slavery. I demonstrate that this was also the case among blacks in Massachusetts, such as Phillis Wheatley, Prince Hall, and Caesar Sarter.'

At one time or another, these three activists employed the rhetorical form of the Puritan jeremiad, yet few scholars have touched on the black jeremiad's origins during the eighteenth century. This sermonic form was a ritual that Puritan ministers had engaged in since the seventeenth century as a means to fight the perceived religious decline among their parishioners. Sacvan Bercovitch's American Jeremiad explores the significance of the jeremiad for American literature and politics into the nineteenth century but does not note its use by black thinkers. Those who do explore blacks' appropriation of the jeremiad, such as Wilson Jeremiah Moses and David Howard-Pitney, focus on nineteenth-century activists such as David Walker and Frederick Douglass. However, I argue that Caesar Sarter initiated the tradition of the black jeremiad with his 1774 essay on slavery, which claimed that blacks were God's new chosen people and that slavery's supporters would soon face God's wrath for their actions. ${ }^{10}$

Studies of Puritanism as a whole and biographies of early-eighteenthcentury Puritan leaders such as Cotton Mather and Samuel Willard do not touch on the implications of Puritan thought and the system of slavery it set up for later black abolitionists. Harry Stout's work on preaching in New England, for instance, devotes one page to the relationship between white revolutionary ideology and abolition but does not examine the thought of African Americans. Richard Lovelace's American Pietism of Cotton Mather has a brief discussion of Mather's justification of social hierarchies but does not explore Mather's thoughts on slavery and their prevalence throughout colonial Massachusetts. Works on Samuel Willard, such as Ernest Benson Lowrie's Shape of the Puritan Mind, similarly neglect to examine Willard's ideas toward slaves. An exception is Richard Bailey's Race and Redemption in Puritan New England, though his study ends at the late colonial period, stopping short of an examination of Calvinism and black abolitionism. ${ }^{11}$

This book builds on these works by developing the important links between Reformed theology, the institution of slavery, and the rise of the antislavery movement. I argue that blacks in Massachusetts initiated organized abolitionism in America and that their antislavery ideology had its origins in Puritan thought and the particular system of slavery that 
this religious ideology shaped in Massachusetts. The political activity of black abolitionists was central in effecting the abolition of slavery and the slave trade within the Bay State, and it was likewise key in building a national antislavery movement in the years of the early republic. Even while abolitionist strategies were evolving, much of the rhetoric and tactics that well-known abolitionists such as William Lloyd Garrison and Frederick Douglass employed in the mid-nineteenth century had their origins among blacks in Massachusetts during the eighteenth century. 